\title{
Phosphorus Availability in Laying Hens Given Non-phytate Phosphorus Deficient Diets Containing Buckwheat
}

\author{
Rakhi Chowdhury ${ }^{1}$ and Katsuki $\mathrm{Koh}^{2}$ \\ ${ }^{1}$ Interdisciplinary Graduate School of Science and Technology, Shinshu University, Minamiminowa, Nagano 399-4598, Japan \\ ${ }^{2}$ Faculty of Agriculture, Shinshu University, Minamiminowa, Nagano 399-4598, Japan
}

To date, the effect of buckwheat phytase on laying hens has not yet been investigated. Thus, this study was conducted to compare the production performance, egg quality, and phosphorus $(\mathrm{P})$ balance of laying hens given nonphytate P deficient diets supplemented with non-germinated buckwheat (BU) or germinated buckwheat (GBU). Experimental diets $(17.8 \% \mathrm{CP}, 2,988 \mathrm{kcal} / \mathrm{kg} \mathrm{ME})$ consisted of two control diets, the positive control (PC), satisfying all nutrient requirements and negative control (NC) containing $0.16 \%$ less non-phytate $\mathrm{P}$ than that in the $\mathrm{PC}$ diet, and six experimental diets (containing 10\%, 15\%, 20\% BU or GBU), prepared by replacing maize with BU or GBU, along with the raw materials of NC diet. Fifty-six laying hens (46 week of age) were allocated to eight dietary groups (seven hens each) and experimental diets were given for a period of six weeks (week one was employed for acclimatization, and the subsequent five weeks for data collection). Deteriorated production performance (hen-day egg production, feed intake, egg weight and egg mass) and eggshell quality (shell breaking strength, shell weight and shell thickness) in laying hens given a non-phytate P deficient NC diet was restored by the addition of at least $15 \% \mathrm{BU}$ and $10 \% \mathrm{GBU}$ to the NC diet. Total P retention significantly increased in $20 \% \mathrm{BU}, 15 \% \mathrm{GBU}$ and $20 \%$ GBU groups as excretion decreased considerably in these groups than the NC group. Considering the hen-day egg production as an economically important parameter, we found that a 340 phytase unit (PU)/kg diet of buckwheat phytase was equivalent to $0.10 \%$ non-phytate $\mathrm{P}$ in laying hens. These results suggested that the addition of buckwheat in non-phytate $\mathrm{P}$ deficient diets can alleviate the deficiency and improve $\mathrm{P}$ availability in laying hens.

Key words: buckwheat, egg production, laying hens, phosphorus balance, phytase

J. Poult. Sci., 56: 58-64, 2019

\section{Introduction}

Dietary phytase is recognized as an important feed additive used to facilitate phosphorus (P) utilization in the monogastric animals by means of phytate $\mathrm{P}$ utilization, and microbial or plant origins (Türk et al., 2000) are used. The former is a commercially available enzyme and is used practically, but there is a disadvantage in the energy input for production and the cost of the product (Han et al., 1998). In contrast, the latter is considered a less labor intensive and environmentally-friendly method: all that is necessary is to include feed ingredients showing high phytase activity such as, barley, triticale and wheat, into diets. These cereals, however, may not be very suitable due to the presence of high levels of $\beta$-glucans (Havrlentová and Kraic, 2006), which are indigestible polysaccharides.

Received: May 10, 2018, Accepted: July 10, 2018

Released Online Advance Publication: August 25, 2018

Correspondence: Dr. Katsuki Koh, Faculty of Agriculture, Shinshu University, Minamiminowa, Nagano 399-4598, Japan.

(E-mail: kkkohss@shinshu-u.ac.jp)
We tried to use buckwheat as a feed ingredient containing phytase in our previous study with broilers because it is a glucan-free pseudocereal containing high phytase activity. Nevertheless, we found that birds showed a normal growth performance and bone quality when germinated buckwheat was added at a $20 \%$ concentration in non-phytate $\mathrm{P}$ deficient diet. In the experiment, a diet of 470 units of buckwheat phytase per $\mathrm{kg}$ was equivalent to $0.10 \%$ of non-phytate $\mathrm{P}$ (Chowdhury and Koh, 2018a). Considering practical use of buckwheat in chicken diets, experiments with laying hens should be made essential as the efficiency of phytate utilization varied between laying hens and broilers (Saitoh, 2001; Edwards Jr.,1982; Nelson, 1976).

Therefore, the aim of this study was to measure the production performance, egg quality and $\mathrm{P}$ balance of laying hens given non-phytate $\mathrm{P}$ deficient diets with buckwheat, and discuss the efficacy of buckwheat phytase at improving $\mathrm{P}$ availability in laying hens, especially in comparison with our previous report with broilers. 


\section{Materials and Methods}

This experiment was conducted in accordance with the guidelines for the regulation of animal experimentation of Shinshu University, Japan.

\section{Germination of Buckwheat}

Seeds of buckwheat (Shinano No. 1 variety) with high phytase activity were purchased commercially and some of seeds were germinated as explained in Chowdhury and Koh, 2018a. Both non-germinated (BU) and germinated seeds (GBU) were ground to pass through a $1.0-\mathrm{mm}$ aperture, and approximately $93 \%$ of the hulls were removed by sieving them. Ground BU and GBU were maintained at room temperature till analysis (Table 1).

\section{Hens, Diets, and Sampling}

Fifty six Lohmann LSL-Lite, laying hens (46 week of age) were divided into eight groups (seven hens each) with similar body weight $(\mathrm{BW})$ and reared in individual cages under a 16L:8D light condition. Hens were allocated to one of the eight experimental diets: a positive control (PC), formulated to meet or exceed the nutrients recommended by NRC (1994), a negative control (NC), containing $0.16 \%$ less nonphytate $\mathrm{P}$ than the $\mathrm{PC}$ diet, and six other diets with $10 \%$, $15 \%$, and $20 \%$ of $\mathrm{BU}$ or GBU in the NC diet using maize (Table 2). Diets with 2,988 kcal $/ \mathrm{kg} \mathrm{ME}, 17.8 \% \mathrm{CP}$, and 3.62
$\%$ calcium were given for six weeks: the first week was allocated to acclimatization, and the subsequent five weeks for data collection. Feed and water were provided ad libitum. Excreta were collected, and immediately stored at $-20^{\circ} \mathrm{C}$. Excreta of each hen were pooled for the three days of collection. Frozen excreta samples were then thawed, homogenized, dried, and ground before analysis.

Table 1. Chemical composition of buckwheat (Shinano No. 1)

\begin{tabular}{lcc}
\hline \hline \multirow{2}{*}{ Components, \% } & \multicolumn{2}{c}{ Shinano No. 1 buckwheat } \\
\cline { 2 - 3 } & BU & GBU \\
\hline Crude protein & 15.71 & 17.02 \\
Ether extract & 2.92 & 2.87 \\
Crude fiber & 5.16 & 5.74 \\
Crude ash & 2.13 & 1.91 \\
Total P & 0.39 & 0.45 \\
Phytate P & 0.33 & 0.27 \\
Phytase activity, $\mathrm{PU}^{2} / \mathrm{g}$ & 2.20 & 2.77 \\
\hline
\end{tabular}

${ }^{1}$ Values based on analysis of triplicate samples (dry matter basis).

${ }^{1} \mathrm{BU}=$ non-germinated buckwheat; $\mathrm{GBU}=$ germinated buckwheat.

${ }^{2}$ Phytase unit (PU) equivalent to the enzymatic activity, which liberates $1 \mu \mathrm{mol}$ inorganic phosphate per min at $\mathrm{pH} 5.5$ and $37^{\circ} \mathrm{C}$.

Table 2. Ingredients and chemical composition of experimental diets (week 46-51) ${ }^{1}$

\begin{tabular}{|c|c|c|c|c|c|c|c|c|}
\hline \multirow{2}{*}{ Ingredients, \% } & \multirow{2}{*}{$\mathrm{PC}$} & \multirow{2}{*}{$\mathrm{NC}$} & \multicolumn{3}{|c|}{$\mathrm{NC}+\mathrm{BU}$} & \multicolumn{3}{|c|}{$\mathrm{NC}+\mathrm{GBU}$} \\
\hline & & & $10 \%$ & $15 \%$ & $20 \%$ & $10 \%$ & $15 \%$ & $20 \%$ \\
\hline Commercial diet ${ }^{2}$ & 33.5 & 33.7 & 34.0 & 34.2 & 34.7 & 34.0 & 34.2 & 34.7 \\
\hline Soybean meal & 19.3 & 19.3 & 17.7 & 17.2 & 16.4 & 17.7 & 17.2 & 16.4 \\
\hline Maize & 38.8 & 38.8 & 28.5 & 22.8 & 17.2 & 28.5 & 22.8 & 17.2 \\
\hline $\mathrm{BU}$ & - & - & 10.0 & 15.0 & 20.0 & - & - & - \\
\hline GBU & - & - & - & - & - & 10.0 & 15.0 & 20.0 \\
\hline Maize oil & 0.45 & 0.45 & 2.05 & 3.05 & 3.95 & 2.05 & 3.05 & 3.95 \\
\hline $\mathrm{CaCO}_{3}$ & 5.7 & 6.4 & 6.4 & 6.4 & 6.4 & 6.4 & 6.4 & 6.4 \\
\hline $\mathrm{Ca}_{3}\left(\mathrm{PO}_{4}\right)_{2}$ & 0.9 & - & - & - & - & - & - & - \\
\hline Vit-min premix ${ }^{3}$ & 1.35 & 1.35 & 1.35 & 1.35 & 1.35 & 1.35 & 1.35 & 1.35 \\
\hline \multicolumn{9}{|c|}{ Analyzed composition, \% (as fed basis) } \\
\hline Crude protein & 17.9 & 17.8 & 17.9 & 17.7 & 17.8 & 17.9 & 17.8 & 17.7 \\
\hline Phytate P & 0.26 & 0.27 & 0.25 & 0.26 & 0.26 & 0.26 & 0.26 & 0.27 \\
\hline Non-phytate P & 0.36 & 0.20 & 0.21 & 0.20 & 0.21 & 0.20 & 0.21 & 0.20 \\
\hline Calcium $^{4}$ & 3.60 & 3.60 & 3.61 & 3.62 & 3.64 & 3.62 & 3.62 & 3.64 \\
\hline $\mathrm{ME}, \mathrm{kcal} / \mathrm{kg}^{4}$ & 2,984 & 2,990 & 2,985 & 2,990 & 2,990 & 2,985 & 2,990 & 2,990 \\
\hline $\begin{array}{l}\text { Phytase, PU/kg of diet on } \\
\text { DM basis }\end{array}$ & ND & ND & 220 & 328 & 440 & 280 & 420 & 564 \\
\hline \multicolumn{9}{|c|}{$\begin{array}{l}{ }^{1} \mathrm{PC}=\text { positive control, } \mathrm{NC}=\text { negative control, } \mathrm{BU}=\text { non-germinated buckwheat, } \mathrm{GBU}=\text { germinated buckwheat, } \mathrm{PU}=\text { phytase } \\
\text { unit; } \mathrm{DM}=\text { dry matter, } \mathrm{ND}=\text { not determined. } \\
{ }^{2} \text { Layer diet }(\mathrm{CP} \geq 17.0 \%, \mathrm{ME} \geq 2,850 \mathrm{kcal} / \mathrm{kg} \text {, Feedone Co., Ltd. Kanagawa, Japan). } \\
{ }^{3} \text { Vitamin-mineral premix provided with the following concentrations per } \mathrm{kg} \text { of diet: vitamin } \mathrm{A}, 1.5 \mathrm{mg} \text {; vitamin } \mathrm{D}_{3}, 0.03 \mathrm{mg} \text {; } \\
\text { vitamin } \mathrm{E}, 7.37 \mathrm{mg} \text {; vitamin } \mathrm{K}_{3}, 1.1 \mathrm{mg} \text {; vitamin } \mathrm{B}_{1}, 6.0 \mathrm{mg} \text {; vitamin } \mathrm{B}_{2}, 23.0 \mathrm{mg} \text {; vitamin } \mathrm{B}_{6}, 8 \mathrm{mg} \text {; vitamin } \mathrm{B}_{12}, 0.02 \mathrm{mg} \text {; } \\
\text { pantothenic acid, } 18 \mathrm{mg} \text {; niacin, } 35 \mathrm{mg} \text {; choline chloride, } 1700 \mathrm{mg} \text {; folacin, } 2.20 \mathrm{mg} \text {; iron, } 95 \mathrm{mg} \text {; copper, } 11 \mathrm{mg} \text {; zinc, } 180 \\
\text { mg; manganese, } 280 \mathrm{mg} \text {; iodine, } 3.4 \mathrm{mg} \text {. }\end{array}$} \\
\hline
\end{tabular}


Table 3. Effects of non-germinated and germinated buckwheat supplemented diets on production performance in laying hens ${ }^{1}$

\begin{tabular}{|c|c|c|c|c|c|c|}
\hline Dietary groups & $\begin{array}{l}\text { Hen-day egg } \\
\text { production, } \%\end{array}$ & $\begin{array}{c}\text { FI, } \\
\mathrm{g} / \mathrm{hen} / \mathrm{d}\end{array}$ & $\begin{array}{l}\text { Egg weight, } \\
\mathrm{g}\end{array}$ & $\begin{array}{l}\text { Egg mass, } \\
\text { g/hen/day }\end{array}$ & $\begin{array}{c}\text { FCR, } \\
\mathrm{g} \text { feed/g eggs }\end{array}$ & $\begin{array}{c}\text { BWC, } \\
\text { g/hen/6 weeks }\end{array}$ \\
\hline $\mathrm{PC}$ & $99 \pm 0.6^{\mathrm{a}}$ & $117.3 \pm 0.2^{\mathrm{a}}$ & $61.2 \pm 0.3^{\mathrm{a}}$ & $60.4 \pm 0.3^{\mathrm{ab}}$ & $1.94 \pm 0.01$ & $6.4 \pm 13.0$ \\
\hline $\mathrm{NC}$ & $93 \pm 0.8^{\mathrm{c}}$ & $111.7 \pm 0.5^{\mathrm{c}}$ & $58.3 \pm 0.3^{\mathrm{b}}$ & $54.3 \pm 0.8^{\mathrm{c}}$ & $2.06 \pm 0.02$ & $-51.4 \pm 16.3$ \\
\hline $\mathrm{NC}+10 \% \mathrm{BU}$ & $95 \pm 1.3^{\mathrm{bc}}$ & $115.9 \pm 0.2^{\mathrm{b}}$ & $60.2 \pm 0.5^{\mathrm{ab}}$ & $57.0 \pm 1.1^{\mathrm{bc}}$ & $2.04 \pm 0.04$ & $-29.3 \pm 20.1$ \\
\hline $\mathrm{NC}+15 \% \mathrm{BU}$ & $97 \pm 0.9^{\mathrm{ab}}$ & $117.0 \pm 0.2^{\mathrm{ab}}$ & $60.4 \pm 0.6^{\mathrm{ab}}$ & $58.7 \pm 1.0^{\mathrm{ab}}$ & $2.00 \pm 0.03$ & $-15.0 \pm 19.1$ \\
\hline $\mathrm{NC}+20 \% \mathrm{BU}$ & $98 \pm 0.8^{\mathrm{ab}}$ & $117.2 \pm 0.3^{\mathrm{a}}$ & $60.6 \pm 0.7^{\mathrm{a}}$ & $59.6 \pm 1.0^{\mathrm{ab}}$ & $1.97 \pm 0.03$ & $-14.7 \pm 22.2$ \\
\hline $\mathrm{NC}+10 \% \mathrm{GBU}$ & $97 \pm 1.1^{\mathrm{ab}}$ & $117.7 \pm 0.2^{\mathrm{a}}$ & $60.6 \pm 0.5^{\mathrm{a}}$ & $58.9 \pm 0.9^{\mathrm{ab}}$ & $2.00 \pm 0.03$ & $-26.4 \pm 18.0$ \\
\hline $\mathrm{NC}+15 \% \mathrm{GBU}$ & $99 \pm 0.6^{\mathrm{a}}$ & $117.7 \pm 0.2^{\mathrm{a}}$ & $61.2 \pm 0.5^{\mathrm{a}}$ & $60.5 \pm 0.6^{\mathrm{ab}}$ & $1.95 \pm 0.02$ & $-20.7 \pm 23.5$ \\
\hline $\mathrm{NC}+20 \% \mathrm{GBU}$ & $99 \pm 0.6^{\mathrm{a}}$ & $118.1 \pm 0.1^{\mathrm{a}}$ & $61.6 \pm 0.4^{\mathrm{a}}$ & $60.8 \pm 0.3^{\mathrm{a}}$ & $1.94 \pm 0.01$ & $-12.9 \pm 19.0$ \\
\hline \multicolumn{7}{|l|}{ Main effects } \\
\hline \multicolumn{7}{|l|}{ Germination } \\
\hline $\mathrm{BU}$ & $96 \pm 0.7$ & $116.7 \pm 0.2^{\mathrm{b}}$ & $60.4 \pm 0.3$ & $58.4 \pm 0.6^{\mathrm{b}}$ & $2.00 \pm 0.02$ & $-19.7 \pm 11.3$ \\
\hline GBU & $98 \pm 0.5$ & $117.9 \pm 0.1^{\mathrm{a}}$ & $61.1 \pm 0.3$ & $60.1 \pm 0.4^{\mathrm{a}}$ & $1.97 \pm 0.01$ & $-20.0 \pm 11.2$ \\
\hline \multicolumn{7}{|l|}{ Concentration } \\
\hline $10 \%$ & $96 \pm 0.9^{\mathrm{b}}$ & $116.8 \pm 0.3^{\mathrm{b}}$ & $60.4 \pm 0.3$ & $57.9 \pm 0.7^{\mathrm{b}}$ & $2.00 \pm 0.02$ & $-27.9 \pm 12.9$ \\
\hline $15 \%$ & $98 \pm 0.6^{\mathrm{ab}}$ & $117.3 \pm 0.2^{\mathrm{a}}$ & $60.8 \pm 0.4$ & $59.6 \pm 0.6^{\mathrm{ab}}$ & $1.97 \pm 0.02$ & $-17.9 \pm 14.6$ \\
\hline $20 \%$ & $99 \pm 0.5^{\mathrm{a}}$ & $117.7 \pm 0.2^{\mathrm{a}}$ & $61.1 \pm 0.4$ & $60.2 \pm 0.5^{\mathrm{a}}$ & $1.96 \pm 0.02$ & $-13.8 \pm 14.1$ \\
\hline \multicolumn{7}{|l|}{ Source of variation } \\
\hline Germination & 0.0544 & $<0.0001$ & 0.0969 & 0.0242 & 0.1868 & 0.9842 \\
\hline Concentration & 0.0171 & 0.0007 & 0.4543 & 0.0322 & 0.7499 & 0.7791 \\
\hline $\begin{array}{l}\text { Germination } \times \\
\text { Concentration }\end{array}$ & 0.5634 & 0.0681 & 0.8240 & 0.9202 & 0.9763 & 0.9740 \\
\hline
\end{tabular}

${ }^{\mathrm{a}-\mathrm{c}}$ Means within a column not followed by common superscripts are different at $P<0.05$.

${ }^{1}$ Values for each parameter represent mean \pm standard error of mean values with seven observations (from 47 to 51 week of age).

${ }^{1} \mathrm{PC}=$ positive control; $\mathrm{NC}=$ negative control; $\mathrm{BU}=$ non-germinated buckwheat; $\mathrm{GBU}=$ germinated buckwheat; $\mathrm{FI}=$ feed intake; FCR $=$ feed conversion ratio; $\mathrm{BWC}=$ body weight change.

\section{Production Performance and Egg Quality}

Egg production and feed intake (FI) were recorded daily. Egg production was calculated on a hen per day basis, and egg mass was calculated from collected data of egg production and egg weight, using the equation: egg mass $(\mathrm{g} / \mathrm{hen})=($ egg production $\times$ egg weight $) /$ period $($ day $)$. Feed conversion ratio (FCR) was calculated as the ratio of grams of feed consumed per grams of egg mass. Eggs were analyzed every day to determine egg quality (egg weight, specific gravity, Haugh unit, and albumen height), and eggshell quality (shell breaking strength, shell weight, and shell thickness). Specific gravity was determined using a graded series of saline solutions varying in specific gravity from 1.060 to 1.146 . Egg weight, eggshell breaking strength, Haugh unit, albumen height, and yolk color were measured using Digital Egg Tester (Nabel Co., Ltd., Kyoto, Japan). Eggshell was weighed after drying at $100^{\circ} \mathrm{C}$ for $2 \mathrm{~h}$, and thickness was measured using a micrometer (PK-1012CPX, Mitutoyo Corporation, Kanagawa, Japan).

\section{Chemical and Statistical Analysis}

Samples of BU, GBU, diets, and excreta were analyzed for proximate composition following the standard methods (AOAC, 1990). Total $\mathrm{P}$ and phytate $\mathrm{P}$ were measured according to ISO (1998) and Haug and Lantzsch (1983), respectively: non-phytate $\mathrm{P}$ was calculated by subtracting the phytate $\mathrm{P}$ from total $\mathrm{P}$. Retention of total $\mathrm{P}$ and nitrogen was the amount of these retained per hen per day, which was calculated based on their availability and feed intake (Um and Paik, 1999).

Phytase activity was measured following the method described by Eeckhout and De Paepe (1994). Briefly, 100 $\mathrm{mg}$ of finely ground dried sample was mixed with a Naphytate solution buffered with acetate at $\mathrm{pH} 5.5$, and then the phosphate ion liberated from phytate was measured colorimetrically. The phytase unit (PU) was defined as the amount of phytase activity which liberated inorganic $\mathrm{P}$ from a $0.0015 \mathrm{M}$ Na-phytate solution, at a rate of $1 \mu \mathrm{mol}$ per min at pH 5.5 and $37^{\circ} \mathrm{C}$.

Statistical significances were determined using Tukey's multiple comparison tests at a significance level of 5\% following a one-way ANOVA (SAS Institute, 2015). In addition, a two-way ANOVA was conducted to test the main effects of germination and concentration, and the interaction between them (by omitting the PC and NC groups). Moreover, a linear regression analysis was conducted to obtain the equations relating phytase concentration in diets with response (hen-day egg production, FI, and eggshell breaking strength), using the SAS statistical package. The linear regression model used was:

$$
Y=a+b \times X
$$

where ' $Y$ ' is the response criterion, ' $a$ ' is the ' $Y$ ' intercept, ' $\mathrm{b}$ ' is the slope of the response criterion and ' $\mathrm{X}$ ' is the con- 
Table 4. Effects of non-germinated and germinated buckwheat supplemented diets on egg and eggshell quality in laying hens ${ }^{1}$

\begin{tabular}{|c|c|c|c|c|c|}
\hline Dietary groups & Haugh unit & $\begin{array}{l}\text { Albumen height, } \\
\mathrm{mm}\end{array}$ & $\begin{array}{l}\text { Shell breaking } \\
\text { strength, kgf } / \mathrm{cm}^{2}\end{array}$ & $\begin{array}{c}\text { Shell weight, } \\
\text { g }\end{array}$ & $\begin{array}{l}\text { Shell thickness, } \\
\text { mm }\end{array}$ \\
\hline $\mathrm{PC}$ & $88.7 \pm 1.4$ & $8.1 \pm 0.2$ & $5.65 \pm 0.05^{\mathrm{b}}$ & $5.93 \pm 0.04^{\mathrm{ab}}$ & $0.60 \pm 0.003^{\mathrm{a}}$ \\
\hline $\mathrm{NC}$ & $88.6 \pm 1.0$ & $7.9 \pm 0.1$ & $4.31 \pm 0.04^{\mathrm{f}}$ & $5.54 \pm 0.04^{\mathrm{d}}$ & $0.58 \pm 0.004^{\mathrm{b}}$ \\
\hline $\mathrm{NC}+10 \% \mathrm{BU}$ & $89.1 \pm 0.4$ & $8.0 \pm 0.1$ & $4.76 \pm 0.04^{\mathrm{e}}$ & $5.72 \pm 0.03^{\mathrm{c}}$ & $0.58 \pm 0.004^{\mathrm{b}}$ \\
\hline $\mathrm{NC}+15 \% \mathrm{BU}$ & $89.7 \pm 0.9$ & $8.2 \pm 0.2$ & $5.24 \pm 0.04^{\mathrm{c}}$ & $5.85 \pm 0.02^{\mathrm{bc}}$ & $0.59 \pm 0.002^{\mathrm{ab}}$ \\
\hline $\mathrm{NC}+20 \% \mathrm{BU}$ & $90.1 \pm 0.6$ & $8.2 \pm 0.1$ & $5.74 \pm 0.03^{\mathrm{ab}}$ & $6.00 \pm 0.02^{\mathrm{a}}$ & $0.60 \pm 0.001^{\mathrm{a}}$ \\
\hline $\mathrm{NC}+10 \% \mathrm{GBU}$ & $90.9 \pm 0.7$ & $8.3 \pm 0.1$ & $5.02 \pm 0.04^{\mathrm{d}}$ & $5.90 \pm 0.03^{\mathrm{ab}}$ & $0.59 \pm 0.001^{\mathrm{ab}}$ \\
\hline $\mathrm{NC}+15 \% \mathrm{GBU}$ & $90.7 \pm 1.2$ & $8.4 \pm 0.2$ & $5.65 \pm 0.04^{\mathrm{b}}$ & $5.95 \pm 0.03^{\mathrm{ab}}$ & $0.60 \pm 0.003^{\mathrm{a}}$ \\
\hline $\mathrm{NC}+20 \% \mathrm{GBU}$ & $91.0 \pm 0.6$ & $8.5 \pm 0.2$ & $5.90 \pm 0.05^{\mathrm{a}}$ & $6.04 \pm 0.05^{\mathrm{a}}$ & $0.60 \pm 0.003^{\mathrm{a}}$ \\
\hline \multicolumn{6}{|l|}{ Main effects } \\
\hline \multicolumn{6}{|l|}{ Germination } \\
\hline $\mathrm{BU}$ & $89.6 \pm 0.4$ & $8.1 \pm 0.1$ & $5.25 \pm 0.09^{\mathrm{b}}$ & $5.86 \pm 0.03^{\mathrm{b}}$ & $0.59 \pm 0.003^{\mathrm{b}}$ \\
\hline GBU & $90.8 \pm 0.5$ & $8.4 \pm 0.1$ & $5.52 \pm 0.08^{\mathrm{a}}$ & $5.97 \pm 0.02^{\mathrm{a}}$ & $0.60 \pm 0.002^{\mathrm{a}}$ \\
\hline \multicolumn{6}{|l|}{ Concentration } \\
\hline $10 \%$ & $89.9 \pm 0.5$ & $8.2 \pm 0.1$ & $4.89 \pm 0.05^{\mathrm{c}}$ & $5.81 \pm 0.03^{\mathrm{c}}$ & $0.58 \pm 0.003^{\mathrm{b}}$ \\
\hline $15 \%$ & $90.2 \pm 0.7$ & $8.3 \pm 0.2$ & $5.44 \pm 0.06^{\mathrm{b}}$ & $5.90 \pm 0.02^{\mathrm{b}}$ & $0.60 \pm 0.002^{\mathrm{a}}$ \\
\hline $20 \%$ & $90.5 \pm 0.4$ & $8.3 \pm 0.1$ & $5.82 \pm 0.04^{\mathrm{a}}$ & $6.02 \pm 0.03^{\mathrm{a}}$ & $0.60 \pm 0.002^{\mathrm{a}}$ \\
\hline \multicolumn{6}{|l|}{ Source of variation } \\
\hline Germination & 0.0677 & 0.0651 & $<0.0001$ & 0.0002 & 0.0032 \\
\hline Concentration & 0.7688 & 0.5925 & $<0.0001$ & $<0.0001$ & $<0.0001$ \\
\hline $\begin{array}{l}\text { Germination } \times \\
\text { Concentration }\end{array}$ & 0.8271 & 0.7854 & 0.0583 & 0.0602 & 0.2015 \\
\hline
\end{tabular}

${ }^{\mathrm{a}-\mathrm{f}}$ Means within a column not followed by common superscripts are different at $P<0.05$.

${ }^{1}$ Values for each parameter represent mean \pm standard error of mean values with seven observations (from 47 to 51 week of age).

${ }^{1} \mathrm{PC}=$ positive control, $\mathrm{NC}=$ negative control, $\mathrm{BU}=$ non-germinated buckwheat, $\mathrm{GBU}=$ germinated buckwheat.

centration of phytase (PU/kg diet) from BU or GBU (calculated values were used).

\section{Results}

\section{Production Performances (Table 3)}

Hen-day egg production in the PC group was about $99 \%$, which decreased $(P<0.05)$ to $93 \%$ in the NC group, but was restored by the addition of at least $15 \% \mathrm{BU}$ and $10 \% \mathrm{GBU}$. Although FI decreased $(P<0.05)$ in the $\mathrm{NC}$ and $10 \% \mathrm{BU}$ groups, the $\mathrm{FI}$ of the other groups were similar to $(P>0.05)$ that of the PC group. Egg weight and egg mass showed a similar trend as FI, except that the $10 \% \mathrm{BU}$ group showed a restored value, whereas FCR was almost similar in all groups. The degree of restoration was greater in GBU groups than in BU groups, in all parameters. Significant differences in FI and egg mass were found for the main effects of germination and concentration, whereas, in hen-day egg production they were only found for the main effect of concentration. No significant differences in egg weight and FCR were observed for both main effects.

\section{Egg Quality (Table 4)}

Egg specific gravity ranged from 1.126 to 1.129 , and yolk color from 10.0 to 10.4 , and did not significantly vary among the dietary groups (data not shown). Moreover, Haugh unit and albumen height were almost similar in all dietary groups. Eggshell quality, such as shell breaking strength and shell weight were deteriorated in the $\mathrm{NC}$ group $(P<0.05)$, and the deteriorated values were restored dose-dependently by the addition of BU and GBU in diets. Although eggshell thickness decreased $(P<0.05)$ in the $\mathrm{NC}$ and $10 \%$ BU groups, in other groups it did not differ $(P>0.05)$ from that of the PC group. Significant differences in shell breaking strength, shell weight, and shell thickness were found for the main effects of germination and concentration, whereas, no significant differences in Haugh unit and albumen height were observed at germination and concentration.

\section{Balance of Total $P$ and Nitrogen (Table 5)}

Total $\mathrm{P}$ intake varied $(P<0.05)$ between the $\mathrm{PC}$ and other groups because of the varied dietary level of $P$, whereas, the variation among the groups, except $\mathrm{PC}$, was due to the varied FI. Excretion of total P decreased considerably in $20 \% \mathrm{BU}$, $15 \%$ GBU and $20 \%$ GBU groups and concomitantly, retention of total $\mathrm{P}$ increased $(P<0.05)$ in these groups compared to the NC group. In this study, all the diets were isonitrogenous, therefore, the decreased $(P<0.05)$ nitrogen intake in the $\mathrm{NC}$ and $10 \% \mathrm{BU}$ groups was because of the lower FI, which resulted in lower $(P<0.05)$ retention of nitrogen in those groups. Significant differences in the excretion of total $\mathrm{P}$ and nitrogen were found at different concentrations, whereas, both germination and concentration significantly affected the retention of total $\mathrm{P}$ and nitrogen.

\section{Discussion}

So far, a lot of research on dietary microbial phytase has 
Table 5. Effects of non-germinated and germinated buckwheat supplemented diets on the balance of total phosphorus and nitrogen in laying hens ${ }^{1}$

\begin{tabular}{|c|c|c|c|c|c|c|}
\hline \multirow[b]{2}{*}{ Dietary groups } & \multicolumn{3}{|c|}{ Total P } & \multicolumn{3}{|c|}{ Nitrogen } \\
\hline & $\begin{array}{l}\text { Intake, } \\
\mathrm{g} / \mathrm{hen} / \mathrm{d}\end{array}$ & $\begin{array}{l}\text { Excretion, } \\
\text { g/hen/d }\end{array}$ & $\begin{array}{l}\text { Retention, } \\
\mathrm{g} / \mathrm{hen} / \mathrm{d}\end{array}$ & $\begin{array}{l}\text { Intake, } \\
\mathrm{g} / \mathrm{hen} / \mathrm{d}\end{array}$ & $\begin{array}{l}\text { Excretion, } \\
\text { g/hen/d }\end{array}$ & $\begin{array}{l}\text { Retention, } \\
\mathrm{g} / \mathrm{hen} / \mathrm{d}\end{array}$ \\
\hline $\mathrm{PC}$ & $0.74 \pm 0.01^{\mathrm{a}}$ & $0.51 \pm 0.02^{\mathrm{a}}$ & $0.23 \pm 0.01^{\mathrm{abc}}$ & $3.43 \pm 0.02^{\mathrm{a}}$ & $1.43 \pm 0.03$ & $2.00 \pm 0.03^{\mathrm{a}}$ \\
\hline $\mathrm{NC}$ & $0.52 \pm 0.01^{\mathrm{cd}}$ & $0.34 \pm 0.01^{\mathrm{b}}$ & $0.18 \pm 0.01^{\mathrm{d}}$ & $3.17 \pm 0.06^{\mathrm{b}}$ & $1.37 \pm 0.03$ & $1.79 \pm 0.05^{\mathrm{b}}$ \\
\hline $\mathrm{NC}+10 \% \mathrm{BU}$ & $0.51 \pm 0.01^{\mathrm{d}}$ & $0.33 \pm 0.02^{\mathrm{bc}}$ & $0.18 \pm 0.02^{\mathrm{cd}}$ & $3.18 \pm 0.06^{\mathrm{b}}$ & $1.39 \pm 0.06$ & $1.80 \pm 0.06^{\mathrm{b}}$ \\
\hline $\mathrm{NC}+15 \% \mathrm{BU}$ & $0.54 \pm 0.003^{\mathrm{bc}}$ & $0.31 \pm 0.01^{\mathrm{bc}}$ & $0.23 \pm 0.01^{\mathrm{abcd}}$ & $3.41 \pm 0.02^{\mathrm{a}}$ & $1.38 \pm 0.04$ & $2.03 \pm 0.04^{\mathrm{a}}$ \\
\hline $\mathrm{NC}+20 \% \mathrm{BU}$ & $0.55 \pm 0.004^{\mathrm{b}}$ & $0.29 \pm 0.01^{\mathrm{c}}$ & $0.26 \pm 0.02^{\mathrm{ab}}$ & $3.40 \pm 0.02^{\mathrm{a}}$ & $1.35 \pm 0.05$ & $2.05 \pm 0.06^{\mathrm{a}}$ \\
\hline $\mathrm{NC}+10 \% \mathrm{GBU}$ & $0.55 \pm 0.003^{\mathrm{b}}$ & $0.34 \pm 0.01^{\mathrm{bc}}$ & $0.21 \pm 0.01^{\mathrm{bcd}}$ & $3.46 \pm 0.02^{\mathrm{a}}$ & $1.49 \pm 0.01$ & $1.96 \pm 0.03^{\mathrm{ab}}$ \\
\hline $\mathrm{NC}+15 \% \mathrm{GBU}$ & $0.57 \pm 0.002^{\mathrm{b}}$ & $0.30 \pm 0.01^{\mathrm{bc}}$ & $0.27 \pm 0.01^{\mathrm{a}}$ & $3.43 \pm 0.01^{\mathrm{a}}$ & $1.37 \pm 0.03$ & $2.06 \pm 0.03^{\mathrm{a}}$ \\
\hline $\mathrm{NC}+20 \% \mathrm{GBU}$ & $0.56 \pm 0.003^{\mathrm{b}}$ & $0.29 \pm 0.01^{\mathrm{c}}$ & $0.28 \pm 0.01^{\mathrm{a}}$ & $3.41 \pm 0.02^{\mathrm{a}}$ & $1.33 \pm 0.03$ & $2.09 \pm 0.04^{\mathrm{a}}$ \\
\hline \multicolumn{7}{|l|}{ Main effects } \\
\hline \multicolumn{7}{|l|}{ Germination } \\
\hline $\mathrm{BU}$ & $0.53 \pm 0.005^{\mathrm{b}}$ & $0.31 \pm 0.01$ & $0.22 \pm 0.01^{\mathrm{b}}$ & $3.33 \pm 0.03^{\mathrm{b}}$ & $1.37 \pm 0.03$ & $1.96 \pm 0.04^{\mathrm{b}}$ \\
\hline GBU & $0.56 \pm 0.003^{\mathrm{a}}$ & $0.30 \pm 0.01$ & $0.25 \pm 0.01^{\mathrm{a}}$ & $3.43 \pm 0.01^{\mathrm{a}}$ & $1.39 \pm 0.02$ & $2.04 \pm 0.02^{\mathrm{a}}$ \\
\hline \multicolumn{7}{|l|}{ Concentration } \\
\hline $10 \%$ & $0.53 \pm 0.007^{\mathrm{b}}$ & $0.33 \pm 0.01^{\mathrm{a}}$ & $0.19 \pm 0.01^{\mathrm{b}}$ & $3.32 \pm 0.05^{\mathrm{b}}$ & $1.44 \pm 0.03^{\mathrm{a}}$ & $1.88 \pm 0.04^{\mathrm{b}}$ \\
\hline $15 \%$ & $0.55 \pm 0.004^{\mathrm{a}}$ & $0.31 \pm 0.01^{\mathrm{ab}}$ & $0.25 \pm 0.01^{\mathrm{a}}$ & $3.42 \pm 0.01^{\mathrm{a}}$ & $1.38 \pm 0.02^{\mathrm{ab}}$ & $2.04 \pm 0.02^{\mathrm{a}}$ \\
\hline $20 \%$ & $0.56 \pm 0.003^{\mathrm{a}}$ & $0.28 \pm 0.01^{\mathrm{b}}$ & $0.27 \pm 0.01^{\mathrm{a}}$ & $3.41 \pm 0.02^{\mathrm{a}}$ & $1.34 \pm 0.03^{\mathrm{b}}$ & $2.07 \pm 0.03^{\mathrm{a}}$ \\
\hline \multicolumn{7}{|l|}{ Source of variation } \\
\hline Germination & $<0.0001$ & 0.5037 & 0.0046 & 0.0001 & 0.4759 & 0.0310 \\
\hline Concentration & $<0.0001$ & 0.0040 & $<0.0001$ & 0.0030 & 0.0473 & 0.0002 \\
\hline $\begin{array}{l}\text { Germination } \times \\
\text { Concentration }\end{array}$ & 0.0562 & 0.5995 & 0.7225 & 0.0630 & 0.2109 & 0.2199 \\
\hline
\end{tabular}

${ }^{\mathrm{a}-\mathrm{d}}$ Means within a column not followed by common superscripts are different at $P<0.05$.

${ }^{1}$ Values for each parameter represent mean \pm standard error of mean values with seven observations.

${ }^{1} \mathrm{PC}=$ positive control, $\mathrm{NC}=$ negative control, $\mathrm{BU}=$ non-germinated buckwheat, $\mathrm{GBU}=$ germinated buckwheat.

found that this enzyme restores impaired production performance in laying hens which are on non-phytate P deficient diets (Hughes et al., 2008; Panda et al., 2005); moreover, it was reported that a $250 \mathrm{PU} / \mathrm{kg}$ diet was equivalent to around $0.10 \%$ non-phytate $\mathrm{P}$ in laying hens (Van Der Klis et al., 1997). However, research on dietary plant phytase remains limited. Scott et al. (2000) suggested that wheat phytase degraded phytate $\mathrm{P}$ in diets and improved phytate $\mathrm{P}$ utilization in laying hens, although phytase units equivalent to $0.10 \%$ non-phytate $\mathrm{P}$ was not shown in this report.

In this study, impaired production performance (hen-day egg production, FI, egg weight, and egg mass) and eggshell quality (shell breaking strength, shell weight, and shell thickness), in the NC group were restored by the addition of at least $15 \%$ of BU and $10 \%$ GBU to NC diet. Furthermore, excretion of $\mathrm{P}$ decreased in laying hens by $35 \%$ to $43 \%$ in $\mathrm{BU}$ and GBU added groups, compared with the PC group, and led to higher retention of total $\mathrm{P}$ in $20 \% \mathrm{BU}, 15 \% \mathrm{GBU}$ and $20 \%$ GBU groups. This may be explained by the increased availability of $\mathrm{P}$ from phytate $\mathrm{P}$ by the activity of buckwheat phytase. When expressing the effect of buckwheat phytase as the amount of non-phytate $\mathrm{P}$, linear relationships between the phytase concentration and economically important parameters, such as hen-day egg production, FI, and eggshell strength, were determined, resulting in the following regression equations:

$$
\begin{aligned}
& \mathrm{Y}_{1}=93+0.011 \mathrm{X}, \mathrm{r}^{2}=0.75 \\
& \mathrm{Y}_{2}=115.6+0.005 \mathrm{X}, \mathrm{r}^{2}=0.53 \\
& \mathrm{Y}_{3}=4.07+0.003 \mathrm{X}, \mathrm{r}^{2}=0.94
\end{aligned}
$$

where $\mathrm{Y}_{1}=$ hen-day egg production $(\%), \mathrm{Y}_{2}=\mathrm{FI}(\mathrm{g} / \mathrm{hen} /$ day $)$, $\mathrm{Y}_{3}=$ shell breaking strength $\left(\mathrm{kgf} / \mathrm{cm}^{2}\right)$, and $\mathrm{X}=$ buckwheat phytase (PU/kg diet).

All the regression equations were significant $(P<0.05)$, except for that of FI $(P=0.0942)$. Consequently, the concentration of phytase required to obtain the same hen-day egg production, FI, and eggshell strength in the PC group were calculated to be 545,340 and $395 \mathrm{PU} / \mathrm{kg}$ diet, respectively. Taking the hen-day egg production as the most important parameter, $545 \mathrm{PU} / \mathrm{kg}$ diet should be included in the NC diet formulated based on the NRC requirement, and therefore, $340 \mathrm{PU} / \mathrm{kg}$ diet of buckwheat phytase may be equivalent to $0.10 \%$ non-phytate $\mathrm{P}$. This value is 1.4 times greater than that of microbial phytase (derived from Aspergillus niger), which was 250 PU/kg diet (Van Der Klis et al., 1997), suggesting that microbial phytase is superior, to some extent, to plant phytase.

It is noteworthy that there are some reports showing a difference in the efficiency of phytate utilization between laying hens and broilers: Edwards Jr. (1982) reported that Leghorn type chickens utilized phytate $\mathrm{P}$ more efficiently than broiler chickens, whereas Nelson (1976) observed that broiler chicks and laying hens showed almost similar effi- 
ciency. Recently, Saitoh (2001) reported that the efficiency of phytate utilization was better in broilers than in laying hens. In our previous study in which buckwheat diets were fed to broilers, $470 \mathrm{PU} / \mathrm{kg}$ diet of buckwheat phytase was equivalent to $0.10 \%$ non-phytate $\mathrm{P}$ in broilers (Chowdhury and Koh, 2018a), which is greater than the corresponding value in this study, and phytase activity in buckwheat used in this study was similar to that used in our previous broiler study (Chowdhury and Koh, 2018a). Consequently, efficiency of phytate utilization was more in laying hens than broilers, at least when buckwheat phytase was used.

The reason why the phytase efficacy differed between chicken strains is still obscure, and the main site of phytate $\mathrm{P}$ degradation needs to be identified. The intestine may not be the site, because, to our knowledge, there are no reports showing that the chicken intestine contributes to phytate degradation. Furthermore, intestinal phytase activity is often diminished as having little importance on phytate degradation (Humer et al., 2015), although phytase activity in the small intestine of laying hens was $35 \%$ higher than in broilers (Maenz and Classen, 1998). On the other hand, the crop is promising because high phytase activity was measured in it in several reports (Chowdhury and Koh, 2018b; Takemasa et al., 1996; Takemasa and Murakami, 1995). Interestingly, Shires et al. (1987) observed a slower rate of feed passages in the crop and esophagus in laying hens than in broilers.

In this study, nitrogen retention was lower in the $\mathrm{NC}$ group than the PC group, and recovered with increasing concentration of BU and GBU dose-dependently: the magnitude of recovery was greater in GBU then in BU. This trend was in accordance with the results of egg weight and egg mass, both of which may need nitrogen to increase their values (Novak et al., 2006; Bunchasak et al., 2005; Keshavarz and Nakajima, 1995). The changes in nitrogen retention may be explained mainly by changes in nitrogen intake because there was no statistical difference in nitrogen excretion among the groups. Interestingly, in our previous study, the nitrogen retention of broilers that received non-phytate $\mathrm{P}$ deficient diets containing BU and GBU, showed similar trend to that in this study, but the mechanism was somewhat different: nitrogen excretion differed significantly among groups, but nitrogen intake was almost similar in all groups (Chowdhury and Koh, 2018a). This suggests that there is a difference in the response of nitrogen balance to non-phytate P deficiency between laying hens and broilers.

Thus, it was clarified that dietary buckwheat restored the impaired production performance and eggshell quality caused by the non-phytate $\mathrm{P}$ deficiency, and improved total $\mathrm{P}$ retention in laying hens. In addition, it was suggested that the buckwheat phytase was somewhat less effective than microbial phytase and laying hens require less phytase than broilers to cope with non-phytate P deficiency.

\section{Conflicts of Interest}

The authors declare no conflict of interest.

\section{References}

Association of Official Analytical Chemists. Official Methods of Analysis. $15^{\text {th }}$ edition. Association of Analytical Chemists, Washington, DC. 1990.

Bunchasak C, Poosuwan K and Nukraew. Effect of dietary protein on egg production and immunity responses of laying hens during peak production period. International Journal of Poultry Science, 4: 701-708. 2005.

Chowdhury R and Koh K. Growth performance, bone quality, and phosphorus availability in broilers given phosphorus-deficient diets containing buckwheat (Fagopyrum esculentum). Journal of Poultry Science, 55: 249-256. 2018a.

Chowdhury R and Koh K. Phytase activity in the digesta from different parts of the digestive tract, and ileal digestibility of nutrients in broilers fed with buckwheat diets. Journal of Poultry Science, 55: 274-279. 2018b.

Edwards Jr. HM. Phosphorus. 1. Effect of breed and strain on utilization of suboptimal levels of phosphorus in the ration. Poultry Science, 62: 77-84. 1982.

Eeckhout W and De Paepe M. Total phosphorus, phytate-phosphorus and phytase activity in plant feedstuffs. Animal Feed Science and Technology, 47: 19-29. 1994.

Han YM, Roneker KR, Pond WG and Lei XG. Adding wheat middling, microbial phytase, and citric acid to corn-soybean meal diets for growing pigs may replace inorganic phosphorus supplementation. Journal of Animal Science, 76: 2649-2656. 1998.

Haug W and Lantzsch HJ. Sensitive method for the rapid determination of phytate in cereals and cereal products. Journal of the Science of Food and Agriculture, 34: 1423-1426. 1983.

Havrlentová M and Kraic J. Content of $\beta$-D-glucan in cereal grains. Journal of Food and Nutrition Research, 45: 97-103. 2006.

Hughes AL, Dahiya JP, Wyatt CL and Classen HL. The efficacy of quantum phytase in a forty-week production trial using white leghorn laying hens fed corn-soybean meal-based diets. Poultry Science, 87: 1156-1161. 2008.

Humer E, Schwarz C and Schedle K. Phytate in pig and poultry nutrition. Journal of Animal Physiology and Animal Nutrition, 99: 605-625. 2015.

ISO. Animal feeding stuffs-Determination of phosphorus contentSpectrometric method. Ref. No ISO 6491: 1998 (E). International Standard ISO 6491 was prepared by the Technical committee ISO/TC 34, Agricultural food products subcommittee SC 10, Animal feeding stuffs. ISO, Geneva, Switzerland. 1998.

Keshavarz K and Nakajima S. The effect of dietary manipulations of energy, protein, and fat during the growing and laying periods on early egg weight and egg components. Poultry Science, 74: 50-61. 1995.

Maenz DD and Classen HL. Phytase activity in the small intestinal brush border membrane of the chicken. Poultry Science, 77: 557-563. 1998.

Nelson TS. The hydrolysis of phytate phosphorus by chicks and laying hens. Poultry Science, 55: 2262-2264. 1976.

Novak C, Yakout HM and Scheideler SE. The effect of dietary protein level and total sulfur amino acid:lysine ratio on egg production parameters and egg yield in Hy-line W-98 hens. Poultry Science, 85: 2195-2206. 2006.

NRC. Nutrient Requirements of Poultry. $9^{\text {th }}$ Revised Edition. National Academic Press, Washington, DC. 1994.

Panda AK, Rama Rao SV, Raju MVLN and Bhanja SK. Effect of 
microbial phytase on production performance of white leghorn layers fed on a diet low in non-phytate phosphorus. British Poultry Science, 46: 464-469. 2005.

Saitoh M. The trend of studies on reducing nutrient excretion in poultry and pigs by nutritional approaches (In Japanese with English abstract). Animal Science Journal, 72: 177-199. 2001.

SAS Institute Inc. SAS/ILM ${ }^{\circledR}$ 14.1 User's Guide. SAS Institute Inc. Cary, NC, USA. 2015.

Scott TA, Kampen R and Silversides FG. The effect of phosphorus, phytase enzyme, and calcium on the performance of layers fed wheat-based diets. Canadian Journal of Animal Science, 80: 183-190. 2000.

Shires A, Thompson JR, Turner BV, Kennedy PM and Goh, YK. Rate of passage of corn-canola meal and corn-soybean meal diets through the gastrointestinal tract of broiler and white leghorn chickens. Poultry Science, 66: 289-298. 1987.

Takemasa M and Murakami H. Reduction of phosphorus excretion of chicks by usage of barley or wheat (in Japanese with English abstract). Japanese Poultry Science, 32: 342-349. 1995.

Takemasa M, Murakami H and Yamazaki. Reduction of phosphorus excretion of chicks by addition of yeast phytase (in Japanese with English abstract). Japanese Poultry Science, 33: 104-111. 1996.

Türk M, Sandberg A-S, Carlsson N-G and Andlid T. Inositol hexaphosphate hydrolysis by baker's yeast. Capacity, Kinetics and degradation products. Journal of Agricultural and Food Chemistry, 48: 100-104. 2000.

Um JS and Paik IK. Effects of microbial phytase supplementation on egg production, eggshell quality, and mineral retention of laying hens fed different levels of phosphorus. Poultry Science, 78: 75-79. 1999.

Van Der Klis JD, Versteegh HAJ, Simons PCM and Kies AK. The efficacy of phytase in corn-soybean meal-based diets for laying hens. Poultry Science, 76: 1535-1542. 1997. 